\title{
Studi Literatur Riset Ekonomi dan Keuangan Islam dalam Jurnal Terindeks Scopus Q1
}

\section{Literature Studies of Islamic Economics and Finance Research in Scopus Indexed Journal Q1}

\author{
Aam Slamet Rusydiana \\ SMART (Sharia Economic Applied Research \& Training) Indonesia Bogor \\ Email: aamsmart@gmail.com
}

\begin{abstract}
This study tries to review the research around Islamic economics and finance on reputable journal. It uses descriptive statistical analysis based on selected 177 article publications or paper related to Islamic economics and finance, with international journal indexed by scopus $Q 1$. The entire sample journal publications have published for five years from 2014 to 2018. The results show that Islamic economics and finance research is still dominated by Islamic banks issues (42\%), followed by Islamic capital market issues (31\%), then Islamic accounting (9\%), Islamic business and marketing (7\%), Islamic monetary (4\%), and other Islamic economics and finance issues (7\%), like takaful, microfinance, halal industry, waqf and economic of hajj. In addition, the average time of journal publication is between 9 and 10 months. There are at least 20 Q1 scopus journals that publish Islamic economics and finance articles and the most research with Pacific-Basin Finance Journal, Journal of Economic Behavior \& Organization, Journal of International Financial Market, Institution \& Money, and Journal of Business Ethics. Furthermore, the comparison of quantitative research $(84 \%)$ is still more than the qualitative approach (16\%).
\end{abstract}

Keywords: Islamic economics literatures, scopus

\begin{abstract}
Abstrak. Studi ini mencoba melihat riset terkait ekonomi dan keuangan Islam pada jurnal bereputasi. Studi ini menggunakan analisis statistik deskriptif berdasarkan 177 artikel publikasi terkait dengan ekonomi dan keuangan Islam terindeks oleh scopus Q1. Seluruh publikasi jurnal sampel telah diterbitkan selama lima tahun mulai 2014 hingga 2018. Hasil penelitian menunjukkan bahwa penelitian ekonomi dan keuangan Islam masih didominasi oleh tema bank syariah (42\%), diikuti oleh tema pasar modal Islam (31\%), kemudian akuntansi Islam ( 9\%), bisnis dan pemasaran Islam (7\%) moneter Islam (4\%), dan masalah ekonomi dan keuangan Islam lainnya (7\%), seperti takaful, keuangan mikro, industri halal, wakaf dan ekonomi haji. Selain itu, waktu rata-rata publikasi jurnal adalah antara 9 hingga 10 bulan. Setidaknya ada 20 jurnal scopus Q1 yang menerbitkan artikel ekonomi dan keuangan Islam dengan yang terbanyak adalah: Pacific-Basin Finance Journal, Journal of Economic Behavior \& Organization, Journal of International Financial Market, Institution \& Money, dan Journal of Business Ethics. Selanjutnya, perbandingan penelitian kuantitatif (84\%) masih lebih banyak dibanding pendekatan kualitatif $(16 \%)$.
\end{abstract}

Kata kunci: Literatur ekonomi Islam, scopus

\section{PENDAHULUAN}

Keuangan Islam di Indonesia baru muncul sekitar tahun 1992 yang dipelopori oleh Bank Muamalat Indonesia. Setelah itu mulai berkembang Bank Umum Syariah (BUS), Unit Usaha Syariah (UUS), Bank Pembiayaan Rakyat Syariah (BPRS), koperasi syariah, asuransi syariah, pegadaian syariah, wakaf, dan Lembaga Keuangan Syariah (LKS) lainnya. Menurut Nurfalah et al. (2018), perbankan syariah relatif lebih stabil dibandingkan dengan perbankan konvensional dalam menghadapi shock baik dari internal maupun eksternal. Hal ini menjadi temuan menarik yang perlu dibuktikan melalui berbagai riset di masa mendatang.

Saat ini ekonomi keuangan Islam sedang mengalami kemajuan baik di negara berkembang atau di negara maju sekalipun. Industri keuangan serta bentuk lembaga ekonomi Islam lain sedang tumbuh, mulai dari Timur Tengah, kawasan Asia, hingga negara-negara Barat seperti Inggris. Di Indonesia, ekonomi Islam dapat dilihat perkembangannya dalam industri keuangan syariah, terutama bank 
syariah yang menjadi entitas paling banyak digunakan pasca krisis moneter 1997 (Rusydiana et al., 2009).

Jika diperhatikan lebih dalam, perkembangan ekonomi Islam di tataran praktik masih belum diimbangi dengan pengembangan ekonomi Islam pada sisi teori. Padahal sebagai sebuah ilmu, ekonomi Islam juga bukan hanya perlu ditransformasikan ke dalam tataran praktis-implementatif, tetapi harus pula diiringi dengan perkembangan di sisi akademis-teoretis. Keduanya harus mengalami perkembangan yang searah. Bila sisi praktis-implementatif mengalami perkembangan, maka sisi akademis-teoretis pun seharusnya ikut mengalami perkembangan. Maka berpijak dari argumentasi tersebut, riset-riset pengembangan keilmuan ekonomi Islam menjadi amat penting.

Dalam hal pengembangan ekonomi dan keuangan Islam yang bersifat akademis-teoritis, Islam memiliki paradigma tersendiri (Siddiqi, 2008). Pertama, isu-isu dan masalah hangat yang sedang dihadapi didekati dengan melihat pengalaman-pengalaman ekonomi (behavior) negara Muslim masa silam dengan segala khazanahnya. Tidak cukup dengan itu, masalah yang ada kemudian dianalisis dengan pendekatan ekonomi kontemporer dengan tools analysis modern. Setelah menghasilkan postulat-postulat, aksioma dan teori-teori ekonomi Islam hasil pengalaman empiris, kemudian dikeluarkan dalam bentuk institusi-institusi dan kebijakan negara yang sifatnya makro dan terintegrasi. Ketika terdapat kekurangan dan ketidaksempurnaan, dilakukanlah evaluasi sehingga dalam jangka panjang model-model yang tadi telah dihasilkan akan menjadi lebih sempurna, establish dan relatif dapat diaplikasikan pada sebanyak-banyaknya tempat dan waktu.

Dari latar belakang tersebut, penulis tertarik untuk membahas mengenai perkembangan riset terkait ekonomi dan keuangan Islam selama 5 tahun terakhir (2014-2018). Beberapa manfaat yang bisa didapat dari penelitian ini yaitu mengetahui sudah sejauh mana potret perkembangan ekonomi dan keuangan Islam di dunia, khususnya yang termasuk dalam publikasi jurnal scopus dengan kriteria Q1 atau kategori jurnal-jurnal yang paling baik.

Penelitian ini penting dan perlu dilakukan karena beberapa hal. Pertama, sebagai guidance atau panduan bagi para peneliti ke depan dalam area riset ekonomi dan keuangan Islam sehingga tidak terjadi pengulangan yang tidak perlu. Kedua, penelitian ini perlu dilakukan agar para akademisi yang tertarik dalam penelitian mengetahui sejauh mana riset ekonomi Islam telah dilakukan dan apa gap yang belum dielaborasi lebih mendalam. Ketiga, hasil riset ini juga menjadi panduan jurnal-jurnal mana yang baik dan bereputasi internasional dalam area dan tema riset ekonomi dan keuangan Islam berikut sub-subtopiknya.

Berdasarkan latar belakang yang dijelaskan di atas, maka perumusan masalah dalam penelitian ini adalah sebagai berikut. Pertama, apa saja area kajian tentang ekonomi dan keuangan Islam dan berapa persentasenya dalam publikasi jurnal terindeks scopus Q1. Selanjutnya, secara pendekatan metodologi penelitian, bagaimana komposisi riset terkait ekonomi dan keuangan Islam secara umum. Lalu bagaimana persentase jumlah publikasi, tipe riset, pendekatan penelitian, subjek bahasan hingga area studi tentang ekonomi dan keuangan Islam selama 5 tahun terakhir (2014-2018). Beberapa pertanyaan tersebut akan dijawab dalam penelitian ini.

\section{TINJAUAN PUSTAKA}

Menurut Chapra (2016), ekonomi Islam merupakan suatu cabang ilmu pengetahuan yang membantu manusia dalam mewujudkan kesejahteraannya melalui alokasi dan distribusi berbagai sumber daya langka sesuai dengan tujuan yang ditetapkan berdasarkan syariah (al-iqtisad al-syariah) tanpa mengekang kebebasan individu secara berlebihan, menciptakan ketidakseimbangan makroekonomi dan ekologi, atau melemahkan solidaritas keluarga dan sosial serta ikatan moral yang terjalin di masyarakat. Sementara menurut Siddiqi (2010), ekonomi Islam adalah tanggapan atau respons para 
pemikir muslim terhadap berbagai tantangan ekonomi pada masa tertentu. Dalam hal ini mereka dituntun oleh Quran dan sunah serta akal melalui ijtihad.

Sejak awal berkembang, ekonomi Islam berawal dari isu terkait perbankan tanpa riba yang kemudian lebih dikenal dengan bank Islam atau bank syariah. Dalam perjalanannya, isu ekonomi Islam menjadi lebih luas cakupannya hingga membahas sektor moneter keuangan dan fiskal. Mulai dari pasar modal Islam hingga zakat. Dari tema asuransi syariah hingga isu terkait industri halal. Dalam riset ini, klaster tema ekonomi dan keuangan Islam dikelompokkan berdasarkan tema yang terbanyak.

Sementara itu, pembahasan serupa terkait studi literatur ekonomi dan keuangan Islam telah dilakukan oleh beberapa peneliti sebelumnya. Narayan \& Phan (2017) menulis terkait isu dan tantangan riset bertopik ekonomi dan keuangan Islam beserta kelemahannya. Demikian juga Hassan \& Aliyu (2018) yang lebih fokus pada survei literatur bertema spesifik perbankan Islam kontemporer dan isu-isu yang dihadapi di masing-masing negara. Penelitian lainnya adalah riset yang dilakukan oleh Rasul (2019), Hassan et al. (2019) juga Mukhlisin \& Komalasari (2018). Rasul (2019) mengelaborasi literatur terkait industri wisata halal, sementara Mukhlisin \& Komalasari (2018) meneliti terkait literatur krisis finansial di dunia dan kaitannya dengan peran ekonomi Islam. Adapun Hassan et al. (2019) membahas lebih dalam terkait tema bank syariah dan kaitannya dengan standar akuntansi dan praktiknya.

\section{Bank Syariah}

Literatur terkait tema bank syariah merupakan isu riset yang paling banyak dan populer. Tercatat sedikitnya 74 artikel atau sekitar $42 \%$ dari total keseluruhan observasi jurnal, meneliti tentang bank syariah baik mikro maupun secara makro. Objek yang digunakan sangat bervariatif dengan kasus di beberapa negara yang mengaplikasikan bank syariah.

Menurut Hassan \& Aliyu (2018), isu riset kontemporer terkait bank syariah di dunia saat ini terbagi dalam beberapa tema utama yakni: (1) Prinsip dan praktik bank syariah di beberapa negara, (2) Pengukuran performa bank syariah, (3) Krisis keuangan dan kesehatan bank syariah, (4) Terkait solvabilitas dan risiko bank syariah, (5) Efisiensi bank syariah, (6) Maqasid syariah, disclosure dan inklusi keuangan, dan (7) Regulasi perbankan syariah. Isu riset lainnya menurut Narayan \& Phan (2017) adalah (8) terkait isu tata kelola atau GCG bank syariah dan (9) Hubungan bank syariah dengan usaha kecil menengah (small medium enterprises).

Beberapa isu riset ke depan terkait bank syariah yang menarik antara lain terkait: (1) Status dan orientasi bank syariah yang lebih bersifat sosial, (2) Paradigma profit loss sharing kaitannya dengan tujuan sosial-ekonomi, stabilitas keuangan dan ketahanan terhadap krisis keuangan, (3) Praktik decoupling bank syariah dan konvensional, (4) Maqasid syariah dan inklusi keuangan, (5) Standar keuangan industri perbankan dan keuangan syariah secara umum, (6) Isu perlindungan konsumen bank syariah, dan (7) ihwal metode, data dan pendekatan riset terkait bank syariah yang perlu standar khusus yang relevan agar menghindari kesalahan pengukuran dan prioritas (Hassan \& Aliyu, 2018).

\section{Pasar Modal Syariah}

Studi literatur terkait tema pasar modal syariah berikut saham syariah merupakan isu riset yang paling banyak setelah industri perbankan Islam. Tercatat sebanyak 55 artikel atau sekitar $31 \%$ dari total keseluruhan observasi jurnal, meneliti tentang pasar modal dan saham syariah. Objek yang digunakan juga sangat bervariatif dengan kasus di beberapa negara yang memiliki objek pasar saham berbasis syariah.

Beberapa tema isu yang menjadi bahan penelitian adalah terkait asset pricing, pasar saham syariah dan interaksi pasar keuangan Islam. Sebagai contoh untuk tema asset pricing, penelitian yang telah dilakukan adalah riset Shafron (2018), Narayan, Phan \& Sharma (2018), dan Zaremba et al. (2018). Sementara terkait pasar saham syariah beberapa riset telah dilakukan oleh Azmat et al. (2016), Azmat, 
Skully \& Brown (2017), dan Naifar \& Hammoudeh (2016). Adapun terkait interaksi pasar modal dan keuangan syariah, penelitian yang dapat dirujuk antara lain riset Naqvi et al. (2018), El-Alaoui et al. (2018) dan Alexakis, Pappas \& Tsikouras (2017).

\section{Akuntansi Syariah}

Tidak seperti isu tentang bank syariah dan pasar saham syariah, literatur terkait akuntansi syariah tidak memiliki jumlah publikasi yang relatif banyak. Tercatat hanya 16 artikel atau sekitar 9\% saja dari total keseluruhan observasi jurnal, yang meneliti tentang tema besar akuntansi dari perspektif Islam. Beberapa contoh penelitian terkait tema ini dilakukan oleh Kamla (2018), Azmi, Mohamad \& Shah (2018) dan Abdelsalam et al. (2014). Demikian juga riset yang dilakukan oleh Hidayah, Lowe \& Woods (2018) dan Kamla \& Haque (2017).

\section{Bisnis dan Pemasaran Syariah}

Literatur terkait tema ini dapat dikategorikan menjadi 2 kelompok: yang berkaitan dengan bisnis syariah dan terkait pemasaran dan perilaku konsumen dari perspektif Islam. Sama halnya dengan penelitian-penelitian terkait tema akuntansi syariah, literatur terkait bisnis dan pemasaran syariah memiliki jumlah publikasi yang relatif sedikit. Tercatat hanya 12 artikel atau sekitar $7 \%$ saja dari total keseluruhan observasi jurnal, yang meneliti tentang tema bisnis dan pemasaran dari perspektif Islam.

Beberapa contoh penelitian terkait tema bisnis dan manajemen syariah telah dilakukan oleh Murphy et al. (2016), De Clercq, Rahman \& Haq (2017), dan Tlaiss (2015). Sementara itu, beberapa contoh riset terkait tema pemasaran syariah dan perilaku konsumen dalam perspektif Islam, dapat ditemukan dalam penelitian yang telah dilakukan oleh Kirchmaier, Prufer \& Trautmann (2018), Aysan et al. (2018), Klein, Turk \& Weill (2017), dan Eid \& El-Gohary (2015). Penelitian lainnya terkait tema pemasaran dalam perspektif Islam dilakukan oleh Blau (2017), Chourou (2018) dan Chen et al. (2016).

\section{Moneter Syariah}

Sama halnya dengan penelitian-penelitian terkait tema akuntansi, bisnis dan pemasaran syariah, tema moneter syariah memiliki jumlah publikasi yang sedikit. Tercatat hanya 7 artikel atau sekitar $4 \%$ saja dari total keseluruhan observasi jurnal, yang meneliti tentang tema moneter dan keuangan perspektif Islam. Beberapa contoh penelitian terkait tema ini telah dilakukan oleh Hamza \& Saadaoui (2018), Abedifar, Hasan \& Tarazi (2016), Abedifar, Giudici \& Hashim (2017), Wanke, Azad \& Barros (2016) serta riset Chattha \& Alhabshi (2018).

\section{Tema Ekonomi-Keuangan Syariah Lain}

Termasuk ke dalam tema ini adalah riset terkait asuransi syariah (takaful), keuangan mikro Islam, industri halal, tema wakaf dan keuangan haji. Tercatat hanya 13 artikel atau sekitar $7 \%$ saja dari total keseluruhan observasi jurnal, yang meneliti tentang tema-tema ini. Beberapa contoh penelitian terkait tema asuransi syariah (takaful) dilakukan oleh Alshammari, Alhabshi \& Saiti (2018), Khan (2015) dan Karbhari et al. (2018). Sementara contoh penelitian terkait tema keuangan mikro Islam dilakukan oleh Rozzani et al. (2017) dan Fianto et al. (2017). Tema penelitian lainnya terkait ekonomi dan keuangan Islam adalah terkait industri halal, tema wakaf dan keuangan haji. Penelitian terkait industri halal dilakukan oleh Yousaf \& Xiucheng (2018), dan Olya \& Al-Ansi (2018). Sementara itu, penelitian terkait wakaf dari seluruh sampel 168 jurnal terindeks Scopus Q1 hanya terdapat 1 paper saja yakni yang dilakukan olah Darus et al. (2017). Adapun penelitian terkait keuangan haji telah dilakukan oleh Abbes \& Abdelhedi-Zouch (2015). 


\section{METODE}

Penelitian ini menggunakan data berupa jurnal penelitian selama periode 2014-2018 yang sudah dipublikasikan dan terindeks scopus Q1 terkait area riset ekonomi dan keuangan Islam. Jurnal- jurnal tersebut dapat diperoleh atau diakses secara online dari jurnal yang telah dipublikasikan. Metodologi yang digunakan dalam penelitian ini adalah, 1) pendekatan metode kualitatif dengan statistik deskriptif studi literatur terhadap 177 jurnal terindeks scopus Q1 dan riset tentang Islamic economics and finance. Metode penelitian kualitatif adalah metode penelitian yang berlandaskan pada filsafat postpositivisme digunakan untuk meneliti pada kondisi objek yang alamiah, (sebagai lawannya adalah eksperimen) di mana peneliti adalah sebagai instrumen kunci, teknik pengumpulan data dilakukan secara triangulasi (gabungan), analisis data bersifat induktif/kualitatif, dan hasil penelitian kualitatif lebih menekankan makna dari pada generalisasi (Sugiyono, 2008).

Penelitian kualitatif bersifat deskriptif. Data yang dianalisis tidak untuk menerima atau menolak hipotesis (jika ada). Hasil analisis tersebut berupa deskripsi atas gejala-gejala yang diamati dan tidak harus berbentuk angka-angka atau koefisien antar variabel (Subana \& Sudrajat, 2005). Menurut Wijaya (2013), statistik deskriptif merupakan bidang ilmu statistik yang mempelajari cara- cara pengumpulan, penyusunan dan penyajian ringkasan data penelitian. Data-data tersebut harus diringkas dengan baik dan teratur, baik dalam bentuk tabel atau presentasi grafik, sebagai dasar untuk berbagai pengambilan keputusan. Penelitian ini diolah dengan menggunakan Ms. Excel.

Penelitian ini menggunakan metode sampling non probabilitas purposive. Sampel bertujuan (purposive) adalah sampel yang memiliki tujuan untuk memahami informasi tertentu. Sampel ini dapat dikelompokkan menjadi sampel keputusan (judgment) yang memilih anggota-anggota sampel yang sesuai dengan beberapa kriteria tertentu atas dasar catatan yang lalu atau tujuan penelitian yang ingin dicapai, dan sampel kuota yaitu sampel dipilih berdasarkan kuota atau kategori tertentunya, memilih responden atas karakteristik relevan tertentu yang menggambarkan dimensi-dimensi (proporsi) populasi (Wijaya, 2013). Kriteria yang dimaksud dalam penelitian ini yaitu 177 publikasi jurnal terkait ekonomi dan keuangan Islam selama 5 tahun terakhir dari tahun 2014-2018.

\section{HASIL DAN PEMBAHASAN}

\section{Jumlah Artikel Periodikal \& Strategi Penjudulan}

Pada bagian ini menjelaskan jumlah publikasi jurnal dari tahun 2014 hingga 2018. Terdapat 177 jurnal yang terpublikasi dan terindeks scopus dengan klaster Q1 yang berhubungan dengan Islamic economics and finance dari observasi 5 tahun terakhir. Gambar 1 menjelaskan distribusi artikel jurnal pertahun yang menunjukkan jumlah jurnal terpublikasi bervariasi dari tahun 2014 hingga 2018 dengan range 14 hingga 65 jurnal. Adapun publikasi jurnal terkait ekonomi dan keuangan Islam terbanyak yaitu pada tahun 2017 (37\%). Sedangkan publikasi jurnal yang lebih sedikit dibandingkan tahun lainnya yaitu pada tahun $2015(8 \%)$.

Terdapat kecenderungan peningkatan jumlah artikel publikasi bertema ekonomi dan keuangan Islam dalam jurnal scopus Q1, di mana pada tahun 2014 hanya berjumlah 19 artikel (11\%), menjadi 32 artikel (18\%) pada 2016 dan 65 artikel (37\%) pada tahun 2017. Jumlah artikel publikasi bertema ekonomi dan keuangan Islam dalam jurnal scopus Q1 memang menurun pada tahun 2018 menjadi 47 artikel (27\%), akan tetapi tahun 2018 ini belum selesai hingga periode Desember 2018 di mana sangat memungkinkan untuk bertambah. Koleksi sampel artikel jurnal dalam penelitian ini adalah hingga bulan September tahun 2018. Sementara itu daftar nama jurnal ekonomi dan keuangan Islam yang lebih lengkap dapat dilihat pada lampiran. 


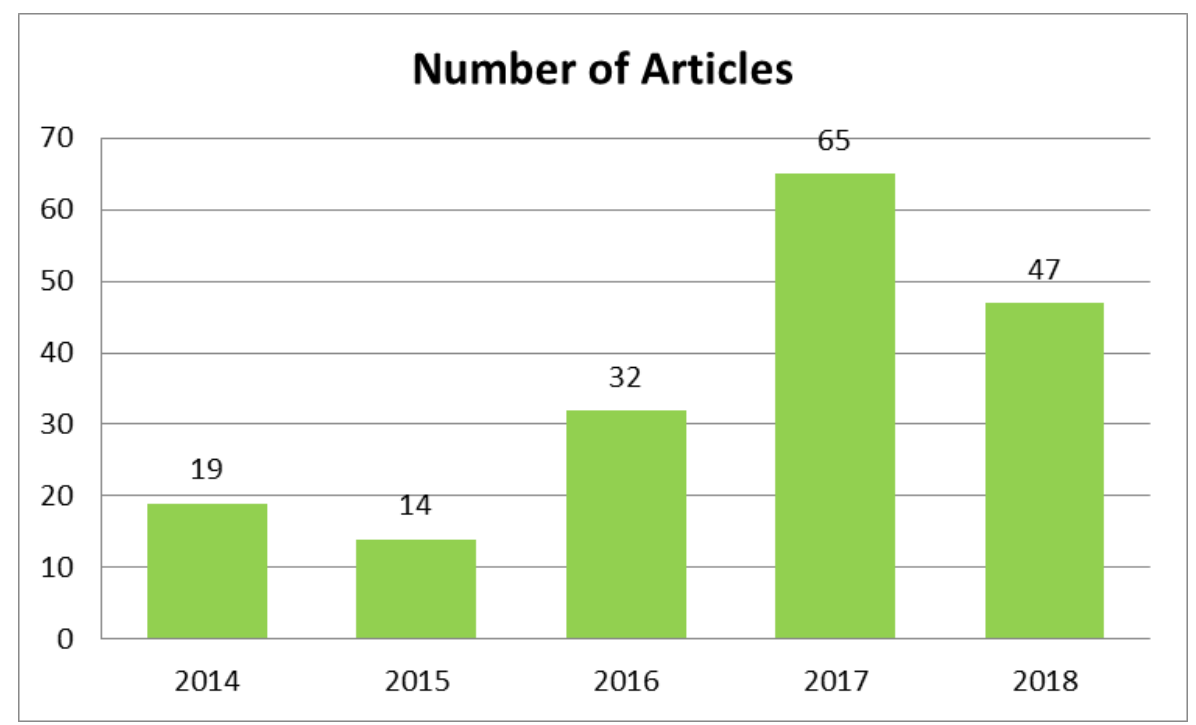

Sumber: Data sekunder, 2018 (diolah)

Gambar 1 Jumlah artikel publikasi per tahun

Ada hal menarik terkait artikel publikasi bertema ekonomi dan keuangan Islam dalam jurnal scopus Q1 yang terkait dengan penjudulan artikel penelitian. Dari total 177 artikel, terdapat 43 artikel publikasi dengan judul berupa pertanyaan atau sekitar $24 \%$ dari total jurnal yang diobservasi. Judul berupa pertanyaan tersebut berdiri sendiri ataupun merupakan kalimat kedua/penjelas dalam judul artikel.

Sementara itu, judul terpendek adalah artikel yang ditulis oleh Fungacova, Hasan \& Weill (2017), yang membahas tentang tingkat kepercayaan masyarakat beberapa negara terhadap institusi perbankan, berjudul "Trust in bank". Adapun artikel dengan judul yang relatif terpanjang adalah penelitian yang dilakukan oleh Hkiri et al. (2017) dengan judul "Are Islamic indexes a safe haven for investors? An analysis of total, directional and net volatility spillovers between conventional and Islamic indexes and importance of crisis periods". Artikel ini membahas tentang perbandingan antara performa indeks saham syariah dan konvensional kaitannya dengan kondisi saat terjadi krisis.

\section{Tema \& Jenis Penelitian Artikel Publikasi}

Gambar 2 menunjukkan beberapa tema penelitian spesifik dalam artikel publikasi bertema ekonomi dan keuangan Islam dalam jurnal scopus Q1. Dari gambar tersebut dapat diketahui bahwa tema penelitian yang terbanyak digunakan dalam artikel jurnal scopus Q1 selama tahun 2014 hingga 2018 adalah tema penelitian terkait bank syariah dengan jumlah 74 artikel (42\%), kemudian diikuti oleh tema penelitian pasar modal syariah sejumlah 55 artikel (31\%). Kedua tema penelitian tersebut adalah yang terbanyak dibanding dengan tema lain seperti akuntansi syariah yang hanya berjumlah 16 artikel (9\%), tema bisnis dan pemasaran syariah dengan 12 artikel (7\%) dan tema moneter syariah 7 artikel $(4 \%)$.

Tema-tema penelitian ekonomi dan keuangan Islam yang lain seperti asuransi syariah (takaful), keuangan mikro Islam, industri halal, tema wakaf dan keuangan haji, hanya berjumlah total 13 artikel atau 7\%. Bahkan, dari total 177 artikel publikasi yang menjadi observasi, tidak ada satupun artikel dengan tema penelitian terkait zakat yang terpublikasi dalam jurnal scopus Q1. Hal ini patut menjadi pertimbangan para peneliti ekonomi dan keuangan Islam agar kemudian memperbanyak penelitian yang berkualitas terkait tema-tema tersebut. Ketersediaan data set yang relatif lengkap dan komprehensif kemungkinan menjadi alasan mengapa riset-riset terkait tema-tema di atas tidak banyak terpublikasi dalam jurnal yang baik dan bereputasi tinggi. 


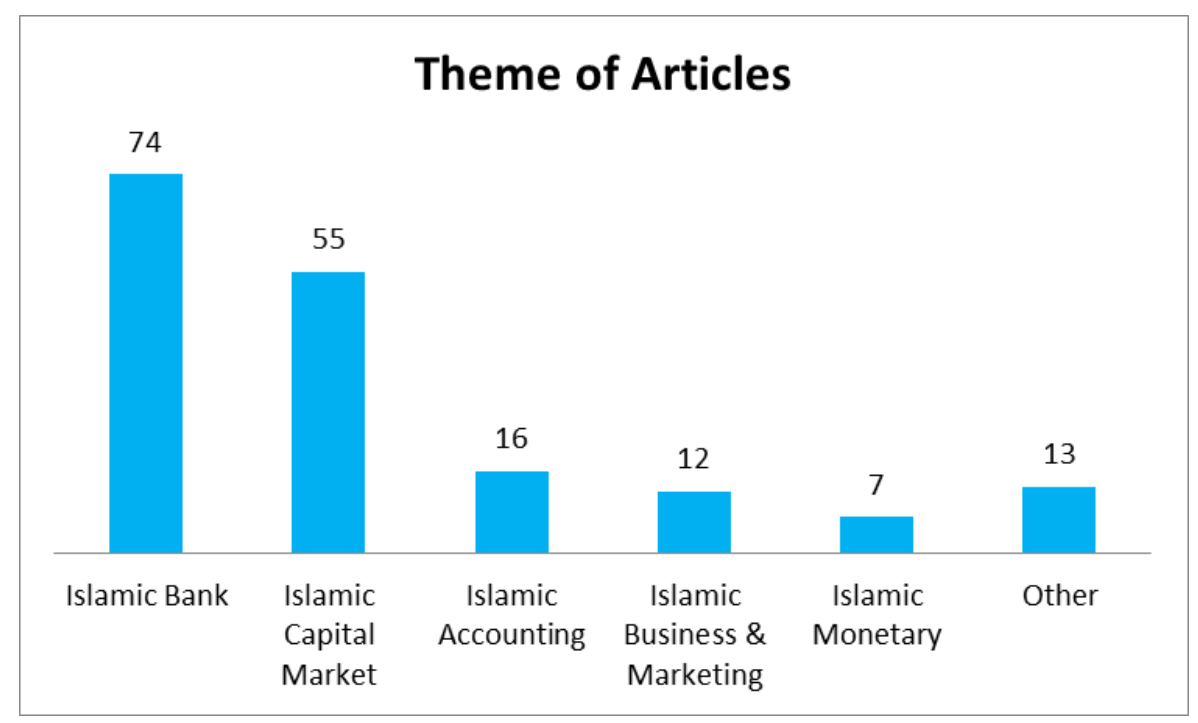

Sumber: Data sekunder, 2018 (diolah)

Gambar 2 Tema penelitian artikel publikasi

Yang menarik adalah dari total 129 artikel publikasi bertema Islamic bank dan Islamic capital market, jumlah penelitian yang membandingkan antara konsep Islamic vs conventional berjumlah cukup banyak yakni sekitar 33 artikel (26\%). Artinya, cukup banyak riset yang hanya bersifat komparasi. Padahal akan jauh lebih baik jika keuangan Islam tidak lagi dapat dilihat dengan cara komparatif. Dengan berdiri lebih independen dari keuangan konvensional akan memungkinkan penelitian dalam keuangan Islam untuk memiliki identitas dan memberikan kontribusi untuk arus utama keuangan yang berbeda dengan jalan keuangan konvensional.

\section{Pendekatan Penelitian Artikel Publikasi}

Berdasarkan Punch (2013), ada 3 jenis pendekatan penelitian yaitu pendekatan kualitatif, pendekatan kuantitatif dan pendekatan metodologi campuran (mixed method). Dalam tulisan ini, artikel publikasi bertema ekonomi dan keuangan Islam dalam jurnal scopus Q1 hanya dibagi dalam 2 kategori yaitu kuantitatif dan kualitatif. Gambar berikut menunjukkan metodologi penelitian yang digunakan untuk setiap jurnal terpublikasi selama kurun waktu 5 tahun terakhir. Dalam observasi ini, pendekatan penelitian yang terbanyak digunakan adalah pendekatan kuantitatif sejumlah 149 artikel atau sebanyak $84 \%$. Sementara itu, jumlah artikel publikasi dengan pendekatan kualitatif sejumlah 28 artikel atau hanya sebanyak $16 \%$.

Hasil temuan penelitian menunjukkan, dari perspektif nature of research, jumlah riset yang bersifat konseptual jauh lebih sedikit dibandingkan dengan riset empiris, dengan perbandingan $9 \%$ dan $91 \%$. Untuk riset yang bersifat konseptual terdiri dari penelitian yang cenderung kualitatif deskriptif dan sebagian berupa pemodelan matematika, sementara untuk riset empiris mayoritas menggunakan pendekatan kuantitatif dan data empiris ekonomi dan keuangan syariah di beberapa negara. 


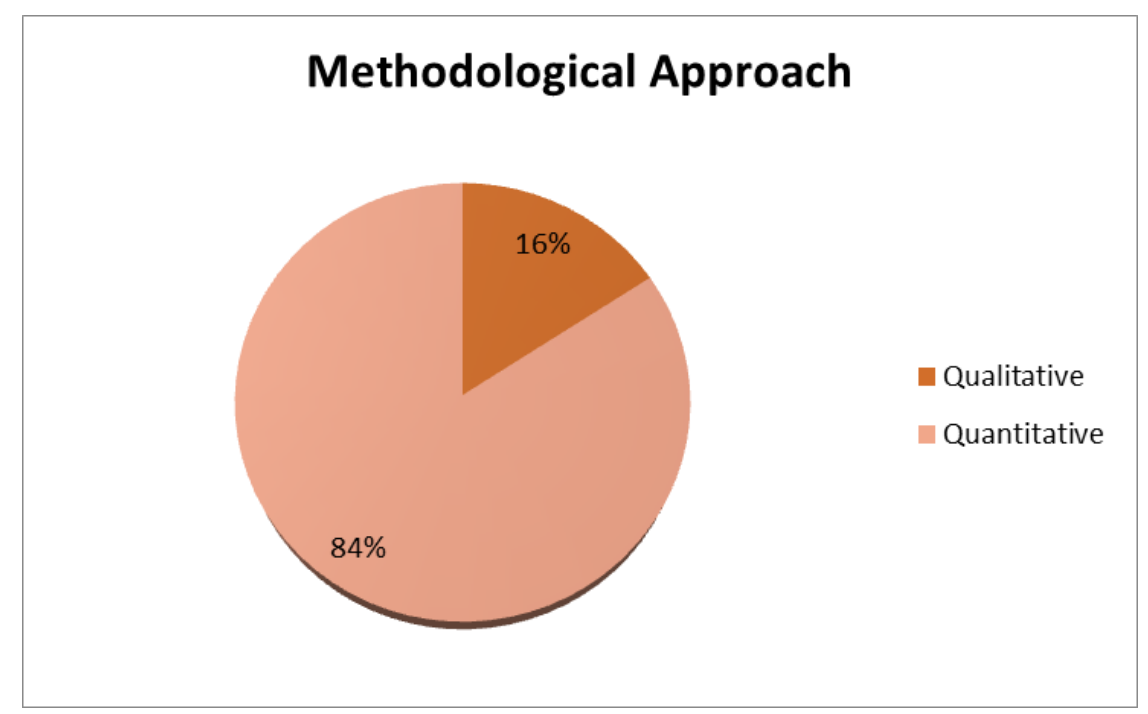

Sumber: Data sekunder, 2018 (diolah)

Gambar 3 Pendekatan penelitian artikel publikasi

Terkait jenis metodologi penelitian kuantitatif yang digunakan dalam jurnal publikasi yang diobservasi, metode yang paling banyak digunakan adalah sebagai berikut: metode Ordinary Least Square (26\%), panel regression (10\%), Generalized Method Moment/GMM (9\%), Metode regresi logistik (logit, probit dan tobit) (8\%), Generalized Autoregressive Conditional Heteroskedasticity/GARCH (7\%), model VAR-Vector Error Correction Model/VECM (5\%), pemodelan matematika (5\%), Stochastic Frontier Analysis/SFA (4\%) dan lain-lain.

Sementara itu, metode estimasi lain yang termasuk dalam pendekatan kuantitatif yang digunakan adalah: Difference in Difference/DID (Halim et al., 2018; Elnahas, Hassan \& Ismail, 2017; Aysan et al., 2017), Structural Equation Model/SEM (Eid \& El-Gohary, 2015), model simultan atau Two Stages Least Square/2SLS (Mahdi \& Abbes, 2018; Blau, 2017), quantile regression (Azad et al., 2018; Naifar, Mroua \& Bahloul, 2017), meta frontier analysis (Safiullah \& Shamsuddin, 2018; Johnes, Izzeldin \& Pappas, 2014), RALS (Solarin, Hammoudeh \& Shahbaz, 2018), bootstraping (Karbhari et al., 2018, Mwamba, Hammoudeh \& Gupta, 2017), Autoregressive Distributed Lag/ARDL (Badeeb \& Lean, 2018), Autoregressive Moving Average/ARMA (Shahzad et al., 2018), Principal Component Analysis/PCA (Bitar, Hassan \& Walker 2017), Markov switching (Hammami \& Oueslati, 2017), Technique for Order of Preference by Similarity to Ideal Solution/TOPSIS (Wanke et al., 2016), Artificial Neural Network/ANN (Wanke, Azad \& Barros, 2016), Data Envelopment Analysis/DEA (Alqahtani, Mayes \& Brown, 2017; Johnes, Izzeldin \& Pappas, 2014), Generalized Linear Mixed Model/GLMM, SNA, Least Square Dummy Variables/LSDV, MV spanning test, survival analysis, Weighted Least Square/WLS dan lain-lain.

Di luar penelitian dengan pendekatan kuantitatif, ada 28 artikel (16\%) yang menggunakan metode kualitatif dalam penelitiannya. Beberapa pendekatan kualitatif tersebut antara lain: indepth interview (Kamla, 2018; Hidayah, Lowe \& Woods, 2018; Riaz, Burton \& Monk, 2017; Kamla \& Haque, 2017), content analysis (Aribi \& Arun, 2014; Yousaf \& Xiucheng; 2018), studi literatur (Hassan \& Aliyu, 2018; Narayan et al., 2017; Linnenluecke et al., 2017, Ibrahim, 2015), penelitian kerangka konseptual, statistik deskriptif, ANOVA, dan lain sebagainya.

Adapun area publikasi dari 177 jurnal Islamic economics and finance terpilih bervariasi yaitu terdapat 20 jurnal. Dalam penelitian ini, Pacific-Basin Finance Journal (PBFJ) menjadi jurnal terbanyak dalam mempublikasikan artikel scopus Q1 terkait riset ekonomi dan keuangan Islam yaitu sejumlah 40 artikel, kemudian diikuti oleh Journal of Economic Behavior \& Organization (25 artikel), Journal of International Financial Market, Institution \& Money (20 artikel), Journal of Business Ethics (19 
artikel), Research in International Business \& Finance (13 artikel), Journal of Corporate Finance dan Emerging Market Review (masing-masing 9 artikel), Journal of Financial Services Research (6 artikel) dan Journal of Banking and Finance, Journal of Financial Stability serta Tourism Management (masing-masing 5 artikel).

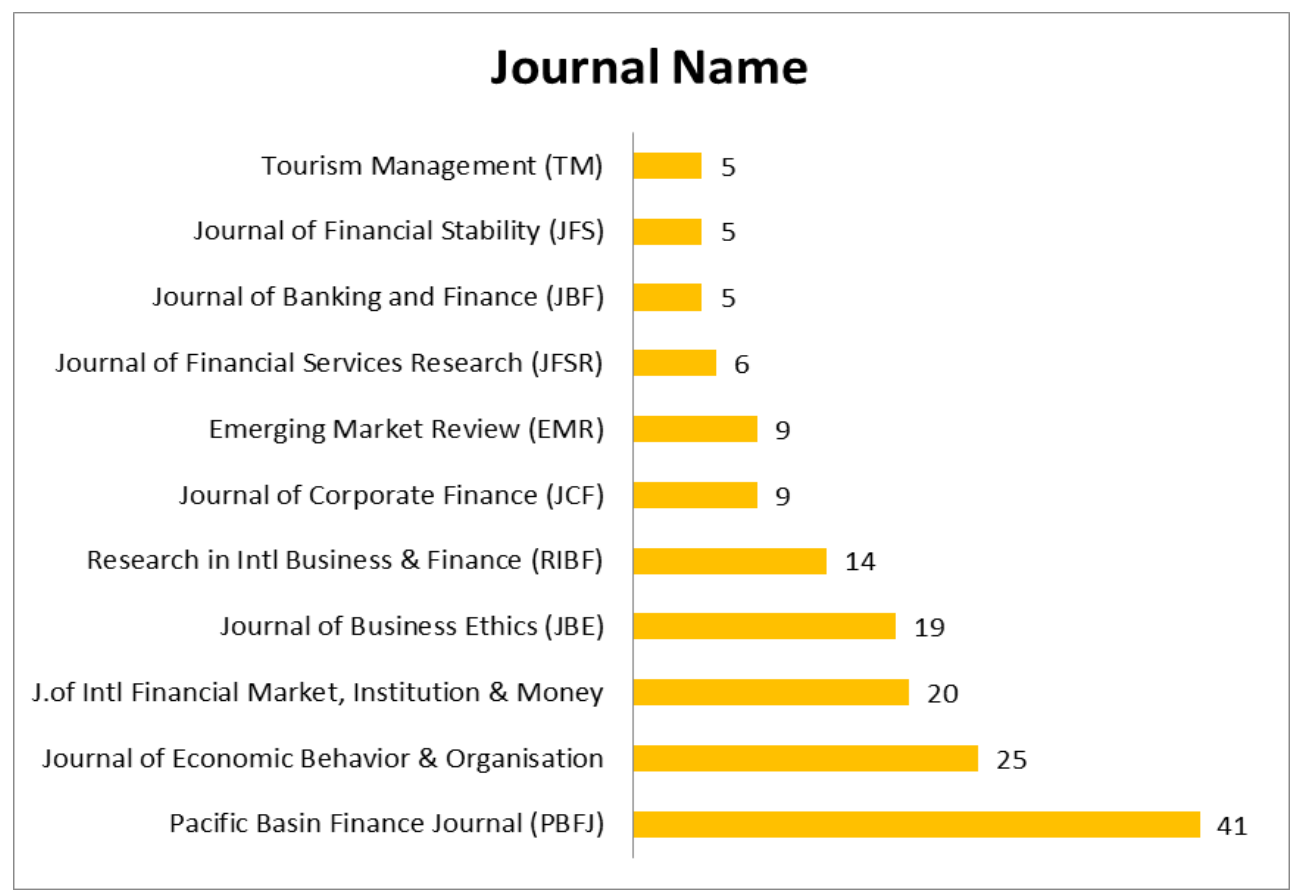

Sumber: Data sekunder, 2018 (diolah)

Gambar 4 Nama publikasi jurnal scopus index Q1

Di luar daftar tersebut, terdapat beberapa jurnal ilmiah yang mempublikasi penelitian terkait ekonomi dan keuangan syariah yang termasuk dalam Q1 jurnal scopus di bawah 5 artikel yaitu: Critical Perspective on Accounting (4 artikel), Business Ethics: A European Review (3 artikel), Energy Economics (3 artikel), Journal of Comparative Economic, Accounting Forum dan Eurasian Business Review (masing-masing 2 artikel), serta jurnal International Economics, Economic Modelling dan Journal of Development Economics masing-masing 1 artikel.

Mayoritas dari ke-20 jurnal tersebut merupakan publikasi dari Elsevier. Seperti kita ketahui, lembaga publikasi internasional Elsevier memiliki kontar pusat di Belanda. Sementara itu, di luar Elsevier terdapat jurnal yang masuk dalam daftar publikasi Springer yang memiliki basis di Jerman. Di luar kedua publisher itu, tidak ada list publikasi lain yang masuk dalam scopus Q1 untuk artikel bertema ekonomi dan keuangan Islam seperti Emerald (UK), Thomson Reuters (Canada), Wiley dan ProQuest (USA) demikian juga Taylor \& Francis (UK).

\section{Temuan Penelitian}

Ada beberapa temuan penting terkait penelitian ini. Analisis 177 publikasi jurnal terkait studi Islamic economics and finance dari tahun 2014 hingga 2018 atau selama 5 tahun terakhir dalam publikasi jurnal terindeks scopus kriteria Q1 adalah sebagai berikut:

1. Terdapat keragaman pembahasan jurnal terkait Islamic economics and finance yang terpublikasi dalam jurnal internasional bereputasi. Jumlah publikasi terbanyak yaitu pada tahun 2017 sebanyak 65 artikel dari 177 sampel. Terdapat kecenderungan peningkatan jumlah artikel publikasi bertema ekonomi dan keuangan Islam dalam jurnal scopus Q1 sejak 2014 hingga 2018. 
2. Umumnya penggunaan pendekatan riset empiris untuk menjawab fenomena penelitian Islamic economics and finance di suatu negara tertentu masih mendominasi metode penelitiannya yaitu sejumlah 162 artikel (91\%) dari 177 sampel artikel jurnal. Sedangkan pendekatan penelitian yang bersifat konseptual hanya sebanyak 15 artikel (9\%).

3. Secara umum dari 177 publikasi jurnal, penggunaan metode pendekatan kuantitatif dalam membahas penelitian Islamic economics and finance adalah sebanyak 149 artikel jurnal (84\%), sementara pendekatan metode kualitatif hanya berjumlah 28 artikel (16\%).

4. Subjek pembahasan 177 publikasi jurnal Islamic economics \& finance tersebut lebih banyak terkait bank syariah dengan jumlah 74 artikel (42\%), kemudian diikuti oleh tema penelitian pasar modal syariah sejumlah 55 artikel (31\%). Kedua tema penelitian tersebut adalah yang terbanyak dibanding dengan tema lain seperti akuntansi syariah yang hanya berjumlah 16 artikel (9\%), tema bisnis dan pemasaran syariah dengan 12 artikel (7\%) dan tema moneter syariah 7 artikel (4\%).

5. Temuan penelitian lainnya adalah, rata-rata waktu penerimaan artikel dari total sampel 177 artikel jurnal publikasi sejak waktu submit hingga paper diterima adalah sekitar 9,5 bulan atau 9-10 bulan dengan periode paling cepat 1 bulan dan paling lama 29 bulan.

6. Penelitian ekonomi dan keuangan Islam dengan kasus Indonesia sangat minim jumlahnya. Tercatat hanya penelitian Fianto et al. (2017) tentang keuangan mikro Islam, dan Shaban et al. (2014) tentang bank syariah.

7. Beberapa penulis terbanyak yang aktif menulis terkait isu ekonomi Islam ini adalah MK Hassan (13 artikel), PK Narayan (9), S Hammoudeh (6), V Pappas (5) dan M.Asutay (4). Penulis yang lainnya adalah: D.Ashraf (4), O.Abdelsalam (4), IO Bacha (4), AMM Masih (4), K Brown (4) dan MH Ibrahim (2).

\section{SIMPULAN}

Fokus penelitian ini adalah mencoba mengetahui sejauh mana perkembangan ekonomi dan keuangan Islam di dunia khususnya yang termasuk dalam publikasi jurnal scopus dengan kriteria Q1 atau kategori jurnal-jurnal yang paling baik. Hasilnya menunjukkan bahwa terdapat kecenderungan peningkatan jumlah artikel publikasi bertema ekonomi dan keuangan Islam terutama dalam jurnal scopus Q1 selama periode 2014-2018.

Pembahasan penelitian Islamic economics and finance didominasi oleh pembahasan isu terkait bank syariah dan pasar saham syariah dari tahun 2014 hingga 2018. Selain itu, perbandingan metode penelitian kuantitatif masih lebih dominan dibandingkan dengan pendekatan kualitatif. Jumlah riset yang bersifat empiris jauh lebih banyak dibandingkan dengan riset yang bersifat konseptual. Hal ini menjadi potensi ke depan untuk meningkatkan penelitian selanjutnya tentang Islamic economics and finance dengan menggunakan metode dan perspektif yang berbeda.

Dalam penelitian ini, 5 besar jurnal dengan artikel publikasi ekonomi dan keuangan Islam terbanyak dalam scopus index journal Q1 adalah: Pacific-Basin Finance Journal (PBFJ), kemudian diikuti oleh Journal of Economic Behavior \& Organization, Journal of International Financial Market, Institution \& Money, Journal of Business Ethics, dan Research in International Business \& Finance. Keseluruhan jurnal tersebut adalah publikasi lembaga penerbit internasional Elsevier.

Menurut Narayan \& Phan (2017), terdapat beberapa ruang improvement untuk riset-riset bertema ekonomi dan keuangan Islam di masa mendatang. Potensi pengembangan tersebut antara lain: (1) Perlunya fokus dalam area riset baru termasuk di dalamnya kelengkapan data set penelitian, (2) Perlunya signifikansi ekonomi dari hasil statistik penelitian, (3) Pentingnya melakukan riset yang mengeksplorasi rumusan dan hipotesis baru dan (4) Perlunya penguatan dari sisi robustness test hasil temuan penelitian. 
Selain itu, penulis menemukan beberapa rekomendasi lain terkait riset-riset bertema ekonomi dan keuangan Islam ke depan. Di antaranya: (5) Perlu lebih banyak jurnal publikasi yang baik, (6) Tetap melakukan riset yang minorstream seperti tema ziswaf meskipun hanya masuk kategori scopus lebih rendah dengan menyiapkan set data yang lebih lengkap, (7) Beberapa tema yang jarang antara lain: takaful, IMFI, halal, ziswaf, dinar, muamalah dan maqasid syariah untuk aplikasi industri keuangan syariah, (8) Perlu lebih banyak kasus riset di Indonesia, (9) Penggunaan metodologi yang lebih bervariatif baik kuantitatif dan kualitatif.

\section{DAFTAR PUSTAKA}

Abbes, M.B., \& Abdelhedi-Zouch, M. (2015). Does hajj pilgrimage affect the Islamic investor sentiment?. Research in International Business and Finance, 35, 138-152.

Abdelsalam, O., Duygun, M., Matallin-Saez, J.C., \& Tortosa-Ausina, E. (2014). Do ethics imply persistence? The case of Islamic and socially responsible funds. Journal of Banking \& Finance, 40, 182-194.

Abedifar, P., Hasan, I., \& Tarazi, A. (2016). Finance-growth nexus and dual banking systems: Relative importance of Islamic banks. Journal of Economic Behavior and Organization, 132, 198-215.

Abedifar, P., Giudici, P., \& Hashem, S.Q. (2017). Heterogeneous market structure and systemic risk: Evidence from dual banking systems. Journal of Financial Stability, 33, 96-119.

El-Alaoui, A. O., Bacha, O. I., Masih, M., \& Asutay, M. (2018). Does low leverage minimise the impact of financial shocks? New optimisation strategies using Islamic stock screening for European portfolios. Journal of International Financial Markets, Institutions and Money, 57, 160-184.

Alexakis, C., Pappas, V. \& Tsikouras, A. (2017). Hidden cointegration reveals hidden values in Islamic investments. Journal of International Financial Markets, Institutions and Money, 46, 70-83.

Alqahtani, F., Mayes, D.G. \& Brown, K. (2017). Islamic bank efficiency compared to conventional banks during the global crisis in the GCC region. Journal of International Financial Markets, Institutions \& Money, 51, 58-74.

Aribi, Z.A. \& Arun, T. (2014). Corporate social responsibility and Islamic financial institutions (IFIs): Management perceptions from IFIs in Bahrain. Journal of Business Ethics, 129(4), 785-794.

Alshammari, A.A., Alhabshi, S.M.S.J. \& Saiti, B. (2018). The impact of competition on cost efficiency of insurance and takaful sectors: Evidence from GCC markets based on the stochastic frontier analysis. Research in International Business and Finance, 47, 410-427.

Aysan, A.F., Disli, M., Duygun, M., \& Ozturk, H. (2017). Islamic banks, deposit insurance reform and market discipline: Evidence from a natural framework. Journal of Financial Services Research, 51(2), 257-282.

Aysan, A.F., Disli, M., Duygun, M., \& Ozturk, H. (2018). Religiosity versus rationality: Depositor behavior in Islamic and conventional banks. Journal of Comparative Economics, 46(1), 1-19.

Azad, A.S.M.S., Azmat, S., Chazi, A., \& Ahsan, A. (2018). Sailing with the non-conventional stocks when there is no place to hide. Journal of International Financial Markets, Institutions \& Money, 57, 1-16.

Azad, A.S.M.S., Azmat, S., Chazi, A., \& Ahsan, A. (2018). Can Islamic banks have their own benchmark?. Emerging Markets Review, 35, 120-136.

Azmat, S., Skully, M. \& Brown, K. (2017). The (little) difference that makes all the difference between Islamic and conventional bonds. Pacific-Basin Finance Journal, 42, 46-59. 
Azmat, S., Jalil, M.N., Skully, M., \& Brown, K. (2016). Investor's choice of shariah compliant 'replicas' and original Islamic instruments. Journal of Economic Behavior \& Organization, $132,4-22$.

Azmi, W., Mohamad, S. \& Shah, M.E. (2018). Nonfinancial traits and financial smartness: International evidence from shariah-compliant and socially responsible funds. Journal of International Financial Markets, Institutions \& Money, 56, 201-217.

Badeeb, R. A., \& c, H. H. (2018). Asymmetric impact of oil price on Islamic sectoral stocks. Energy Economics, 71, 128-139.

Bitar, M., Hassan, M.K. \& Walker, T. (2017). Political systems and the financial soundness of Islamic banks. Journal of Financial Stability, 31, 18-44.

Blau, B.M. (2017). Religiosity and the volatility of stock prices: A cross-country analysis. Journal of Business Ethics, 144(3), 609-621.

Chapra, M. U. (2016). Islam and The Economic Challenges. UK, The Islamic Foundation.

Chattha, J.A. \& Alhabshi, S.M. (2018). Benchmark rate risk, duration gap and stress testing in dual banking systems. Pacific-Basin Finance Journal.

Chen, H., Huang, H.H., Lobo, G.J. \& Wang, C. (2016). Religiosity and the cost of debt. Journal of Banking \& Finance, 70, 70-85.

Chourou, L. (2018). Does religiosity matter to value relevance? Evidence from US banking firms. Journal of Business Ethics, 1-23.

Darus, F., Shukri, N.H.A., Yusoff, H., Ramli, A., Zain, M.M., \& Bakar, N.A.A. (2017). Empowering social responsibility of Islamic organizations through waqf. Research in International Business and Finance, 42, 959-965.

De Clercq, D., Rahman, Z. \& Haq, I.U. (2017). Explaining helping behavior in the workplace: The interactive effect of family-to-work conflict and Islamic work ethic. Journal of Business Ethics, 155(4), 1167-1177.

Eid, R. \& El-Gohary, H. (2015). The role of Islamic religiosity on the relationship between perceived value and tourist satisfaction. Tourism Management, 46, 477-488.

Elnahas, A.M., Hassan, M.K. \& Ismail, G.M. (2017). Religion and ratio analysis: Towards an Islamic corporate liquidity measure. Emerging Markets Review, 30, 42-65.

Elnahas, A.M., Hassan, M.K. \& Ismail, G.M. (2017). Religion and mergers and acquisitions contracting: The case of earnout agreement. Journal of Corporate Finance, 42, 221-246.

Fianto, B.A., Gan, C., Hu, B., \& Roudaki, J. (2017). Equity financing and debt-based financing: Evidence from Islamic microfinance institutions in Indonesia. Pacific-Basin Finance Journal, $52,163-172$.

Fungacova, Z., Hasan, I. \& Weill, L. (2017). Trust in banks. Journal of Economic Behavior \& Organization, 157, 452-476.

Halim, Z.A., How, J., Verhoeven, P., \& Hassan, M.K. (2018). The value of certification in Islamic bond offerings. Journal of Corporate Finance, 55, 141-161.

Hammami, Y., \& Oueslati, A. (2017). Measuring skill in the Islamic mutual fund industry: Evidence from GCC countries. Journal of International Financial Markets, Institutions \& Money, 49, 15-31.

Hamza, H. \& Saadaoui, Z. (2018). Monetary transmission through the debt financing channel of Islamic banks: Does PSIA play a role?. Research in International Business and Finance, 45, 557-570.

Hassan, M.K., Aliyu, S., Huda, M., \& Rashid, M. (2019). A survey on Islamic finance and accounting standards. Borsa Istanbul Review, 19, 1-13. 
Hassan, M.K. \& Aliyu, S. (2018). A contemporary survey of Islamic banking literature. Journal of Financial Stability, 34, 12-43.

Hidayah, N.N., Lowe, A., \& Woods, M. (2018). Accounting and pseudo spirituality in Islamic financial instiutions. Critical Perspectives on Accounting, 61, 22-37.

Hkiri, B., Hammoudeh, S., Aloui, C., \& Yarovaya, L. (2017). Are Islamic indexes a safe haven for investors? An analysis of total, directional and net volatility spillovers between conventional and Islamic indexes and importance of crisis periods. Pacific-Basin Finance Journal, 43, 124150.

Ibrahim, M.H. (2015). Issues in Islamic banking and finance: Islamic banks, shariah-compliant investment and sukuk. Pacific-Basin Finance Journal, 34, 185-191.

Johnes, J., Izzeldin, M. \& Pappas, V. (2014). A comparison of performance of Islamic and conventional banks 2004-2009. Journal of Economic Behavior \& Organization, 103, 93-107.

Kamla, R. (2018). Religion-based resistance strategies, politics of authenticity and professional women accountants. Critical Perspectives on Accounting, 59, 52-69.

Kamla, R. \& Haque, F. (2017). Islamic accounting, neo-imperialism and identity staging: The accounting and auditing organization for Islamic financial institutions. Critical Perspectives on Accounting, 63.

Karbhari, Y., Muye, I., Hasan, A.F.S., \& Elnahass, M. (2018). Governance mechanism and efficiency: Evidence from an alternative insurance (takaful) market. Journal of International Financial Markets, Institutions \& Money, 56, 71-92.

Khan, H. (2015). Optimal incentives for takaful (Islamic insurance) operators. Journal of Economic Behavior and Organization, 109, 135-144.

Kirchmaier, I., Prufer, J. \& Trautmann, S.T. (2018). Religion, moral attitudes and economic behavior. Journal of Economic Behavior and Organization, 148, 282-300.

Klein, P-O., Turk, R. \& Weill, L. (2017). Religiosity vs well-being effects on investor behavior. Journal of Economic Behavior and Organization, 138, 50-62.

Linnenluecke, M.K., Chen, X., Ling, X., Smith, T., \& Zhu, Y. (2017). Research in finance: A review of influential publications and a research agenda. Pacific-Basin Finance Journal, 43, 188199.

Mahdi, I.B.S. \& Abbes, M.B. (2018). Relationship between capital, risk and liquidity: A comparative study between Islamic and conventional banks in MENA region. Research in International Business and Finance, 45, 588-596.

Mahdi, I.B.S. \& Abbes, M.B. (2018). Behavioral explanation for risk taking in Islamic and conventional banks. Research in International Business and Finance, 45, 577-587.

Mukhlisin, M. \& Komalasari, R. (2018). Do you capture financial crisis?. Journal of Islamic Monetary Economics and Finance, 3(2), 1-48.

Murphy, M.J., MacDonald, J.B., Antoine, G.E., \& Smolarski, J.M. (2016). Exploring muslim attitudes towards corporate social responsibility: Are Saudi business students different?. Journal of Business Ethics, 154(4), 1103-1118.

Mwamba, J.W.M., Hammoudeh, S. \& Gupta, R. (2017). Financial tail risks in conventional and Islamic stock markets: A comparative analysis. Pacific-Basin Finance Journal, 42, 60-82.

Naifar, N., Mroua, M., and Bahloul, S. (2017). Do regional and global uncertainty factors affect differently the conventional bonds and sukuk? New evidence. Pacific-Basin Finance Journal, 41, 65-74.

Naifar, N. \& Hammoudeh, S. (2016). Dependence structure between sukuk (Islamic bonds) and stock market conditions: An empirical analysis with archimedean copulas. Journal of International Financial Markets, Institutions \& Money, 44, 148-165. 
Narayan, P.K., Phan, D.H.B. \& Sharma, S.S. (2018). Does Islamic stock sensitivity to oil prices have economic significance?. Pacific-Basin Finance Journal, 53, 497-512.

Narayan, P. K. \& Phan, D. H. B. (2017). A survey of Islamic banking and finance literature: Issues, challenges and future directions. Pacific-Basin Finance Journal, 53, 484-496.

Nurfalah, I., Rusydiana, A. S., Laila, N., \& Cahyono, E. F. (2018). Early warning to banking crises in the dual financial system in Indonesia: The markov switching approach. JKAU: Islamic Economics, 31(2), 133-156.

Olya, H.G.T. \& Al-Ansi, A. (2018). Risk assessment of halal products and services: Implication for tourism industry. Tourism Management, 65, 279-291.

Punch, K.F. (2013). Introduction to Social Research: Quantitative and Qualitative Approaches. SAGE Publishing.

Rasul, T. (2019), The trends, opportunities and challenges of halal tourism: a systematic literature review. Tourism Recreation Research, 44(4), 434-450.

Riaz, U., Burton, B. \& Monk, L. (2017). Perceptions on Islamic banking in the UK: Potentialities for empowerment, challenges and the role of scholars. Critical Perspectives on Accounting, 47, 39-60.

Riaz, U., Burton, B. \& Monk, L. (2017). Perceptions on the accessibility of Islamic banking in the UK: Challenges, opportunities and divergence in opinion. Accounting Forum, 41(4), 353-374.

Naqvi, B., Rizvi, S. K. A., Mirza, N., \& Reddy, K. (2018). Religion based investing and illusion of Islamic Alpha and Beta. Pacific-Basin Finance Journal, 52, 82-106.

Rozzani, N., Mohamed, I.S. \& Yusuf, S.N.S. (2017). Risk management process: Profiling of Islamic microfinance providers. Research in International Business and Finance, 41, 20-27.

Rusydiana, A.S. (2009). Ekonomi Islam Substantif. Jakarta (ID), GP Press.

Safiullah, M., and Shamsuddin, A. (2018). Risk in Islamic banking and corporate governance. Pacific-Basin Finance Journal, 47, 129-149.

Shaban, M., Duygun, M., Anwar, M., \& Akbar, B. (2014). Diversification and banks' willingness to lend to small business: Evidence from Islamic and conventional banks in Indonesia. Journal of Economic Behavior \& Organization, 103, 39-55.

Shafron, E. (2018). Investor tastes: Implications for asset pricing in the public debt market. Journal of Corporate Finance, 55, 6-27.

Shahzad, S.J.H., Mensi, W., Hammoudeh, S., Rehman, M., \& Al-Yahyaee, K.H. (2018). Extreme dependence and risk spillovers between oil and Islamic stock markets. Emerging Markets Review, 34, 42-63.

Shahzad, S.J.H., Hernandez, J.A., Bekiros, S., Shahbaz, M., and Kayani, G.M. (2018). A systemic risk analysis of Islamic equity markets using vine copula and delta coVar modeling. Journal of International Financial Markets, Institutions \& Money, 56, 104-127.

Siddiqi, M.N. (2008). Obstacles of research in Islamic economics. Journal of King Abdulaziz University: Islamic Economics, 21(2), 81-93.

Siddiqi, M.N. (2010). Role of the State in the Economy: An Islamic Perspective. UK, The Islamic Foundation.

Solarin, S.A., Hammoudeh, S. \& Shahbaz, M. (2018). Influence of economic factors on disaggregated Islamic banking deposits: Evidence with structural breaks in Malaysia. Journal of International Financial Markets, Institutions \& Money, 55, 13-28.

Subana dan Sudrajat. (2005). Dasar-dasar Penelitian Ilmiah. Bandung (ID), Pustaka Setia.

Sugiyono. (2008). Metode Penelitian Kuantitatif, Kualitatif, dan R\&D. Bandung (ID), Alfabeta.

Tlaiss, H.A. (2015). How Islamic business ethics impact women entrepreneurs: Insights from four Arab middle eastern countries. Journal of Business Ethics, 129(4), 859-877. 
Wanke, P., Azad, M.A.K., Barros, C.P., \& Hassan, M.K. (2016). Predicting efficiency in Islamic banks: An integrated multicriteria decision making (MCDM) approach. Journal of Internationa Fin.Markets, Institutions \& Money, 45, 126-141.

Wanke, P., Azad, M.A.K. \& Barros, C.P. (2016). Financial distress and the Malaysian dual banking system: A dynamic slacks approach. Journal of Banking \& Finance, 66, 1-18.

Wijaya, T. (2013). Metodologi Penelitian Ekonomi dan Bisnis Teori dan Praktek. Yogyakarta (ID), Graha Ilmu.

Yousaf, S. \& Xiucheng, F. (2018). Halal culinary and tourism marketing strategies on government websites: A preliminary analysis. Tourism Management, 68, 423-443.

Zaremba, A., Karathanasopoulos, A., Maydybura, A., Czapkiewicz, A., \& Bagheri, N. (2018). Dissecting anomalies in Islamic stocks: Integrated or segmented pricing? Pacific-Basin Finance Journal. 


\section{LAMPIRAN}

Lampiran. Jurnal dengan Publikasi bertema Ekonomi dan Keuangan Islam

\begin{tabular}{|c|c|c|c|c|}
\hline PUBLISHER & NO & JOURNAL NAME & GRADE* & TOPIC*** \\
\hline \multirow{17}{*}{ Elsevier } & 1 & Pacific-Basin Finance Journal & Scopus Q1 & ICM; IB \\
\hline & 2 & Research in International Business \& Finance & Scopus Q1 & IB; ICM \\
\hline & 3 & Journal of Intl Financial Market Institutions-Money & Scopus Q1 & ICM; IB \\
\hline & 4 & Journal of Financial Stability & Scopus Q1 & $\mathrm{IB}$ \\
\hline & 5 & Journal of Economic Behavior \& Organization & Scopus Q1 & ICM; IB \\
\hline & 6 & Journal of Corporate Finance & Scopus Q1 & ICM; IB \\
\hline & 7 & Journal of Banking \& Finance & Scopus Q1 & IB; ICM \\
\hline & 8 & Emerging Market Review & Scopus Q1 & $\mathrm{IB} ; \mathrm{ICM}$ \\
\hline & 9 & Critical Perspective of Accounting & Scopus Q1 & IA \\
\hline & 10 & Energy Economics & Scopus Q1 & ICM \\
\hline & 11 & Tourism Management & Scopus Q1 & IM \\
\hline & 12 & World Development & Scopus Q1 & IB; ICM \\
\hline & 13 & Borsa Istanbul Review & Scopus Q2 & ICM; IB \\
\hline & 14 & Economic Modelling & Scopus Q2 & IB; ICM \\
\hline & 15 & Review of Financial Economics & Scopus Q2 & ICM; IB \\
\hline & 16 & International Review of Financial Analysis & Scopus Q2 & ICM; IB \\
\hline & 17 & Journal of Multinational Financial Management & Scopus Q2 & IB; ICM \\
\hline \multirow[t]{10}{*}{ Springer } & 18 & Journal of Business Ethics & Scopus Q1 & IB; IWE; ICM \\
\hline & 19 & Journal of Financial Services Research & Scopus Q1 & IB \\
\hline & 20 & European Journal of Law Economic & Scopus Q2 & $\mathrm{IB} ; \mathrm{M}$ \\
\hline & 21 & Journal of Management \& Governance & Scopus Q2 & IB \\
\hline & 22 & Comparative Economic Studies & Scopus Q3 & IB \\
\hline & 23 & International Journal of Disclosure \& Governance & Scopus Q3 & IA \\
\hline & 24 & Journal of Asset Management & Scopus Q3 & ICM \\
\hline & 25 & Journal of Banking Regulation & Scopus Q3 & IB \\
\hline & 26 & Journal of Financial Services Marketing & Scopus Q3 & IB; IM \\
\hline & 27 & Journal of Knowledge Economics & Scopus Q3 & IB \\
\hline \multirow[t]{20}{*}{ Emerald } & 28 & Benchmarking: An International Journal & Scopus Q1 & IB \\
\hline & 29 & British Food Journal & Scopus Q1 & IM \\
\hline & 30 & Humanomic/Intl Journal of Ethics \& Systems & Scopus Q2 & IE; ISF; T \\
\hline & 31 & International Journal of Bank Marketing & Scopus Q2 & IB; IM \\
\hline & 32 & $\begin{array}{l}\text { International Journal of Islamic and Middle } \\
\text { Eastern Finance \& Management }\end{array}$ & Scopus Q2 & IB; ISF; ICM \\
\hline & 33 & Journal of Islamic Accounting\&Business Research & Scopus Q2 & IA; IB; T \\
\hline & 34 & Journal of Islamic Marketing & Scopus Q2 & IM; IB; T \\
\hline & 35 & Journal of Management Development & Scopus Q2 & IWE \\
\hline & 36 & Management Research Review & Scopus Q2 & IB; IM \\
\hline & 37 & Studies in Economics \& Finance & Scopus Q2 & $\mathrm{IB}$ \\
\hline & 38 & Social Responsibility Journal & Scopus Q2 & IA; IB \\
\hline & 39 & ISRA International Journal of Islamic Finance & WoS & M; ISF \\
\hline & 40 & International Journal of Law \& Management & Scopus Q3 & $\mathrm{M}$ \\
\hline & 41 & International Journal of Managerial Finance & Scopus Q3 & IB \\
\hline & 42 & International Journal of Social Economics & Scopus Q3 & ISF; IE \\
\hline & 43 & Managerial Finance & Scopus Q3 & IB; ICM; ISF \\
\hline & 44 & Qualitative Research in Financial Markets & Scopus Q3 & ICM; IB \\
\hline & 45 & Accounting Research Journal & Scopus Q4 & IA \\
\hline & 46 & International Finance Review (Book Ch) & Scopus Q4 & IE; IB \\
\hline & 47 & The Journal of Risk Finance & Scopus Q4 & $\mathrm{IB}$ \\
\hline \multirow[t]{4}{*}{ TaylorFrancis } & 48 & Journal of Management Spirituality \& Religion & Scopus Q1 & IWE; IM \\
\hline & 49 & Applied Economics & Scopus Q2 & ICM; IB \\
\hline & 50 & Emerging Markets Finance \& Trade & Scopus Q2 & ICM; IB \\
\hline & 51 & Journal of Intl Food \& Agribusiness Marketing & Scopus Q2 & $\mathrm{IM}$ \\
\hline
\end{tabular}




\begin{tabular}{|c|c|c|c|c|}
\hline & 52 & Journal of Food Products Marketing & Scopus Q2 & IM \\
\hline & 53 & Applied Economics Letters & Scopus Q3 & IB; ICM \\
\hline & 54 & Applied Financial Economics & Scopus Q3 & IB; ICM \\
\hline & 55 & Cogent Economics \& Finance & Scopus Q3 & IB; ICM \\
\hline \multirow[t]{5}{*}{ Wiley } & 56 & Business Ethics & Scopus Q2 & IWE \\
\hline & 57 & Thunderbird International Business Review & Scopus Q2 & IB; ICM \\
\hline & 58 & The Muslim World & Scopus Q2 & ISF \\
\hline & 59 & International Journal of Finance \& Economics & Scopus Q2 & $\mathrm{IB}$ \\
\hline & 60 & Accounting \& Finance & Scopus Q2 & IA \\
\hline \multirow[t]{5}{*}{ Sage } & 61 & Accounting History & Scopus Q1 & IA \\
\hline & 62 & Marketing Theory & Scopus Q1 & IM \\
\hline & 63 & Business \& Society & Scopus Q1 & $\mathrm{IB}$ \\
\hline & 64 & Global Business Review & Scopus Q2 & IB; ICM \\
\hline & 65 & Journal of Macromarketing & Scopus Q2 & IM \\
\hline \multirow[t]{13}{*}{ Inderscience } & 66 & Intl Journal of Entrepreneurship \&Small Business & Scopus Q2 & IWE \\
\hline & 67 & Global Business \& Economics Review & Scopus Q3 & ICM \\
\hline & 68 & Intl Journal of Business \& Globalisation & Scopus Q3 & IM; IWE \\
\hline & 69 & Intl Journal of Business Governance \& Ethic & Scopus Q3 & IB; IWE \\
\hline & 70 & Intl Journal of Business Performance Management & Scopus Q3 & $\mathrm{IB}$ \\
\hline & 71 & Intl Journal of Monetary Economics \& Finance & Scopus Q3 & IB; ICM \\
\hline & 72 & Intl Journal of Trade \& Global Markets & Scopus Q3 & IB; ICM \\
\hline & 73 & Afro-Asian Journal of Finance \& Accounting & Scopus Q4 & IB; IA \\
\hline & 74 & Intl Journal of Economic \& Business Research & Scopus Q4 & IWE; IB \\
\hline & 75 & Intl Journal of Economic Policy in Emerging Econ & Scopus Q4 & IB; ISF \\
\hline & 76 & Intl Journal of Managerial \& Financial Accounting & Scopus Q4 & IA; ICM \\
\hline & 77 & Intl Journal of Tourism Policy & Scopus Q4 & IM \\
\hline & 78 & Journal of Global Business Advancement & Scopus Q4 & $\mathrm{IM} ; \mathrm{IB} ; \mathrm{IE}$ \\
\hline \multirow[t]{3}{*}{ WorldScientific } & 79 & Intl Journal of Theoretical \& Applied Finance & Scopus Q1 & IB; ICM \\
\hline & 80 & Journal of Developmental Entrepreneurship & Scopus Q3 & IM \\
\hline & 81 & Journal of Intl Commerce, Economics \& Policy & Scopus Q3 & $\mathrm{IB}$ \\
\hline \multirow[t]{3}{*}{$\begin{array}{l}\text { Business } \\
\text { Perspective }\end{array}$} & 82 & Problems \& Perspectives in Management & Scopus Q3 & $\mathrm{IB}$ \\
\hline & 83 & Banks and Bank Systems & Scopus Q4 & $\mathrm{IB}$ \\
\hline & 84 & Investment Management \& Financial Innovations & Scopus Q4 & $\mathrm{IB} ; \mathrm{IE}$ \\
\hline \multirow[t]{5}{*}{ AlliedAcademie } & 85 & Journal of Entrepreneurship Education & Scopus Q3 & IWE \\
\hline & 86 & Academy of Accounting \& Financial Studies & Scopus Q4 & IA; IWE; IB; T \\
\hline & 87 & Academy of Strategic Management Journal & Scopus Q4 & IB; IWE \\
\hline & 88 & Journal of Legal Ethical \& Regulatory Issue & Scopus Q4 & IB \\
\hline & 89 & International Journal of Entrepreneurship & Scopus Q4 & IM \\
\hline \multirow[t]{2}{*}{ IIJ } & 90 & The Journal of Derivatives & Scopus Q2 & ICM \\
\hline & 91 & The Journal of Private Equity & Scopus Q4 & ICM \\
\hline Malaysian J. & 92 & Global Journal Al-Thaqafah [USAS] & Scopus Q2 & ISF; M; IB; IM \\
\hline USM & 93 & Asian Academy of Management Journal & Scopus Q3 & IWE; IB \\
\hline UM & 94 & Asian Journal of Business \& Accounting & Scopus Q3 & IA; IB \\
\hline IIUM & 95 & Al-Shajarah & Scopus Q3 & ISF; M; IB; T \\
\hline UniMas & 96 & International Journal of Business Society & Scopus Q3 & IB; IA; M; ISF \\
\hline UPM & 97 & International Journal of Economic \& Management & Scopus Q3 & IB; ISF; IM \\
\hline IIUM & 98 & Intellectual Discourse & Scopus Q3 & ISF; M; IE \\
\hline UKM & 99 & Jurnal Ekonomi Malaysia & Scopus Q3 & IB \\
\hline UPM & 100 & Journal of Social Science \& Humanities & Scopus Q3 & ICM; IB; ISF \\
\hline UKM & 101 & Jurnal Pengurusan & Scopus Q3 & IB; ISF; IA \\
\hline UTM & 102 & Jurnal Teknologi & Scopus Q3 & IB; ICM; ISF \\
\hline UM & 103 & Malaysian Journal of Economic Studies & Scopus Q3 & $\mathrm{IB}$ \\
\hline UKM & 104 & Asian Journal of Accounting \& Governance & WoS & IB; IA \\
\hline IIUM & 105 & Intl Journal of Econ. Management \& Accounting & WoS & ISF; IE; IB; M \\
\hline IIUM & 106 & Law Journal & WoS & ISF; M \\
\hline USM & 107 & Asian Academy of Management Journal of & Scopus Q4 & ICM; IB \\
\hline
\end{tabular}




\begin{tabular}{|r|l|l|l|l|}
\hline & & Accounting \& Finance & & \\
\hline UM & 108 & Institutions and Economies & Scopus Q4 & IB; T \\
\hline Indonesian J. & 109 & Studia Islamika [UIN Jkt] & Scopus Q2 & ISF \\
\hline UIN Sby & 110 & Journal of Indonesian Islam & Scopus Q2 & M \\
\hline UIN Ygy & 111 & Al-Jamiah & Scopus Q3 & ISF; M \\
\hline UII & 112 & Economic Journal of Emerging Market & WoS & IB \\
\hline UI & 113 & Indonesian Capital Market Review & WoS & ICM \\
\hline UI & 114 & The South East Asian Journal of Management & WoS & IM \\
\hline UGM & 115 & Gajah Mada International Journal of Business & Scopus Q4 & IB; ISF; IA \\
\hline IAIN Salatiga & 116 & Indonesian Journal of Islam \& Muslim Societies & Scopus Q4 & ISF; M \\
\hline STAIN Kudus & 117 & Qudus International Journal of Islamic Studies & Scopus Q4 & ISF \\
\hline Other Journal & 118 & Intl Journal of Energy Economics \& Policy [EJ] & Scopus Q1 & ICM \\
\hline KAU & 119 & JKAU Islamic Economics & Scopus Q3 & ISF; IB; IE; IA \\
\hline CESMAA & 120 & Journal of Applied Economic \& Science & Scopus Q3 & ICM; IB \\
\hline SESRIC & 121 & Journal of Economic Cooperation \& Development & Scopus Q3 & ISF; IB; IE \\
\hline UT & 122 & Iranian Economic Review & Scopus Q3 & ICM; IE \\
\hline RCIE & 123 & Turkish Journal of Islamic Economics & WoS & IB; IE; ISF; M \\
\hline IBTRA & 124 & Journal of Islamic Economics, Banking \& Finance & Scopus Q4 & ISF; IB; IE; T \\
\hline CEEOL & 125 & Business \& Economic Horizons & Scopus Q4 & IB \\
\hline BRILL & 126 & Arab Law Quarterly & Scopus Q4 & M; IB \\
\hline ICC & 127 & Islamic Quarterly & Scopus Q4 & ISF; IE \\
\hline IRTI & 128 & Islamic Economic Studies & & IE; ISF; IB; M \\
\hline
\end{tabular}

*Data on December 2018

** IB=Islamic bank (incl Monetary), ICM=Islamic capital market, IM=Islamic marketing (incl Halal), IA=Islamic accounting, IWE=Islamic work ethic, M=Muamalah, IE=Islamic economics, ISF=Islamic social finance (incl Ziswaf \& Microfinance), T=Takaful. 